\title{
The Science Transfer Series: Science Reaching the Clinical Practitioner
}

\footnotetext{
To open this special series of interviews, the Revista Odonto Ciência (Journal of Dental Science) talked to Dr. Jaime Cury and Dr. Cassiano Rösing about their experiences lecturing to dental clinicians and carrying out their intense academic and research activities. Dr. Cury is an expert in Cariology and Oral Biochemistry and was recently awarded the 2010 Yngve Ericsson Prize for Research in Preventive Odontology. Dr. Rösing's main areas of research are Periodontics and Oral Epidemiology, and he has co-authored a best-selling book on Evidence-Based Dentistry.
}

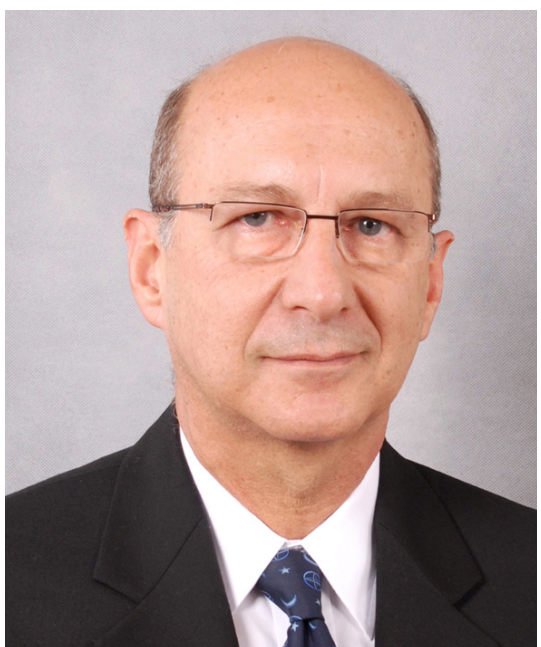

Jaime A. Cury

State University of Campinas

Piracicaba, SP, Brazil

E-mail: jcury@fop.unicamp.br

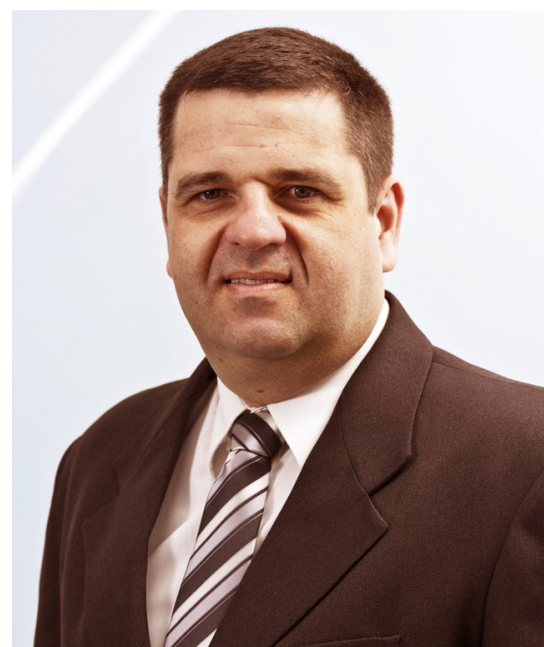

\section{Cassiano K. Rösing}

Federal University of Rio Grande do Sul

Porto Alegre, RS, Brazil

E-mail: ckrosing@hotmail.com
- Revista Odonto Ciência (Journal of Dental Science) - You both have long histories of internationally renowned dental research, and you are both highly productive scientists as well as very active advocates of public health policies for oral health in Brazil. Why do you choose to dedicate so much time to lecture in Brazil and abroad, even for small audiences in the countryside?

$\square$ Dr. Jaime A. Cury - I do this because I feel fulfilled as a teacher and believe that when I am teaching someone I am helping the society that pays my salary as a faculty member of a public university.

$\square$ Dr. Cassiano K. Rösing - I understand that research has the function of generating knowledge, which has to be disseminated. Lecturing to professionals in dentistry has an important regional impact and brings a very significant payback. Furthermore, to contribute to the translation and dissemination of scientific knowledge is the function of a teacher. The most important thing is not the number of people in the audience, but the interest of the present attendants and the geographic area covered. I am a faculty member of a public university and have this obligation to my society.

Rev Odonto Cienc-How many lectures and courses did you give the last year? What is the return for this activity for you?

$\square$ Dr. Cury - Last year I gave 13 official lectures, which is about one per month. I include my e-mail in the first and last slides of all my presentations and ask people to contact me for any further information they need. My greatest return is when I receive a message from a colleague craving something more. 
Dr. Rösing - In 2010, I lectured 28 times in the five major regions of Brazil and also in Argentina and Uruguay. The return for this activity is the perspective of contributing to changes in dental practices, always with the priority of disseminating evidence-based dentistry. Talking to colleagues from other places and exchanging e-mails is very interesting. Several times, I have ended up helping colleagues through the Internet in the planning of clinical cases or interpretation of scientific papers, and people have asked for suggestions for research activities and program organization. It is very rewarding to know that the lecture/course generated interest and challenged colleagues. This is the role of the university faculty.

- Rev Odonto Cienc - What is your vision regarding the partnership with industries and companies of the oral health area in these lectures and courses directed to the clinical community?

$\square$ Dr. Rösing - Industry is a great partner of these practices in health. However, it is clear that faculty members who lecture with sponsorship should not assume the role of marketing. In my understanding, it is fundamental that the faculty members who lecture at sponsored activities do not hide it. For example, I use to present a conflict of interest declaration and tell the audience that I was there in a sponsored activity. This did not change my approach to the subject matter of the lecture; it simply gave the audience the information. I also think that the teaching profession should be highly valued and that all teachers should be paid for all lectures. Unfortunately, this is not the way it usually happens. I give courses and lectures by invitation from professional associations without payment, even if this means financial loss. In fact, the satisfaction of contributing is so large that we do it pro-bono.

$\square$ Dr. Cury - As long as scientific freedom is preserved and respected, I do not see anything wrong from the ethical point of view. Besides, in the legal aspect, this activity is permitted in the work contract with my university and I can receive payment. Furthermore, the industries and companies are filling a gap in professional continuing education that should be made available by professional associations. For example, I have participated as a guest speaker in the symposiums promoted by Colgate at CIOSP (São Paulo International Congress of Dentistry) for the last five years, and I have received payment without asking for it; I also report the income properly.
However, if the CIOSP had invited me to lecture, as done this year, I would do it the same way and for free! Therefore, make you be respected!

- Rev Odonto Cienc-What is the difference in the way a course is prepared and conducted for clinicians and recently graduated professionals compared to the deep content of academic seminars and graduate programs?

$\square$ Dr. Cury - The difference is the focus. The clinician attends the course and thinks the next day about how he/she will apply that knowledge with the first patient occupying his/her dental chair. Thus, it is necessary that the lecturer prepares and presents the content according to the clinician's expectations. On the other hand, it is possible to present the same slide in an academic seminar and in a course for clinicians but with different focuses. This requires much reflection and mental concentration from the lecturer.

$\square$ Dr. Rösing - The teacher who lectures to clinicians should keep in mind that the audience is interested in practical and more immediate answers. This does not mean to vulgarize the information and underestimate the comprehension of dental professionals. It is fundamental that clinical practice should be based in science and, therefore, the clinician needs to get used to understanding research results. The time of mere presentations of clinical cases is over. Thus, I try to illustrate each topic with scientific results and demonstrate case reporting. I am totally opposed to the underestimation of the capacity of dental professionals.

- Rev Odonto Cienc - What is your message for young faculty and researchers who wish to contribute to the development of dentistry and the improvement of oral health in the general population?

$\square$ Dr. Rösing-I am enthusiastic about the dental profession and the youngsters; I challenge them to continue to produce knowledge, be curious with questions that have already been answered, remove their prejudices and be open to change. Dentistry has evolved immensely, and continued learning is important. Thus, the teacher has to be a stimulus for the student. For a new and truly contemporary dentistry, the researcher, the faculty and the clinician must be receptive to new discoveries.

$\square$ Dr. Cury - Work, generate new knowledge and disseminate it because you will feel rewarded for being useful to the society you belong to! 